\title{
Evaluation of thermal stability of an antifungal protein from Bacillus subtilis isolated in Vietnam
}

\author{
Đánh giá tính bền nhiệt của protein có hoạt tính kháng nấm tù chủng Bacillus \\ subtilis phân lập ở Việt Nam
}

Research article

Do Thi Tuyen ${ }^{1,2}$, Le Thanh Hoang ${ }^{1}$, Nguyen Thi Thao ${ }^{1}$, Nguyen Thi Trung ${ }^{2}$, Nguyen Sy Le Thanh ${ }^{1}$, Vũ Thị Bích Ngọc ${ }^{1}$

${ }^{1}$ Institute of Biotechnology, Vietnam Academy of Science and Technology, 18 Hoang Quoc Viet Road, Cau Giay Distr., $10600 \mathrm{Ha}$ Noi, Vietnam; ${ }^{2}$ Graduate University of Science and Technology, Vietnam Academy of Science and Technology, 18 Hoang Quoc Viet Road, Cau Giay Distr., 10600 Ha Noi, Vietnam

\begin{abstract}
Antifungal proteins were isolated from the crude bacterial supernatant using ammonium sulfate salt precipitation followed by passage over DEAE - cellulose and Biogel P100 columns. The purified protein had an apparent molecular mass of $14 \mathrm{kDa}$. Its antifungal activity was retained even at $100^{\circ} \mathrm{C}$, for $60 \mathrm{~min}$. The results of protein identification using MALDI -TOF/TOF mass spectrometer suggested that the purified protein is indeed a chitin binding protein that has 206 acid amine containing chitin -bind -3 region with a relative molecular mass of $22230 \mathrm{Da}$.
\end{abstract}

Protein có hoạt tính kháng nấm được tinh sạch tù dịch ngoại bào chủng vi khuẩn Bacillus subtilis sau khi qua ba bước tinh sạch: tủa muối ammonium sulphate 30-70\%, qua cột sắc ký trao đổi ion DEAE - cellulose và cột săc ký lọc gel Biogel P100. Protein tinh sạch có khối luợng phân tư đạt $22 \mathrm{kDa}$ trên điện di SDS-PAGE. Hoạt tính kháng nấm của protein tinh sạch vẫn còn duy trì khi ủ ở $100^{\circ} \mathrm{C}$ trong 60 phút. Kết quả nhận dạng bằng khối phổ MALDI-TOF/TOF đã chỉ ra rằng protein bền nhiệt này là chitin binding protein được mã hóa bởi 206 acid amin cùng với khối luợng phân tư là $22230 \mathrm{Da}$. trị an toàn đối với Al và Atrazie trong môi trưòng nước tự nhiên về khía cạnh bảo vệ súc khỏe sinh thái.

Keywords: Antifungal protein, Bacillus subtilis, Chitin binding protein, Purification

\section{Introduction}

In the 20th century the number of pesticides, based on biocidal molecules, are the main tool to increase production and quality of food and fiber products. Due to health issues and the environment, the use of many chemicals has caused controversy and needs to be replaced. In addition to self-resistance of cereal crops, mainly other biocontrol measures are based on whole body to suppress pests. Some other approaches to biologically active substances to be tested and some commercial preparations increased. However, it still requires a lot of bio-products using high biotechnology to replace chemicals drug. Currently biocontrol preparations can not be compared with the chemical because of effectiveness, market and other factors, but they still have a promising future, especially the use of the genetically modified strains [1].

To produce biological preparations against plant pathogenic fungi one can conduct the following researches: (1) Screening of antagonistic microorganisms. (2) Studying the effect of culture supernatants of antagonistic microorganisms to plant pathogenic fungi, plants, animals and humans. (3) Optimization of production of antagonistic microorganism. (4) Production of antagonistic preparations used as antifungal reagents or fertilizer additive. (5) Study on chemical structures and effects of secondary compounds in cell culture fragments and antagonistic microorganisms against pathogens. (6) Improving the production of secondary compounds by recombinant DNA technology. (7) Study on the 
mechanism of action of pure secondary compounds against pathogens.

In the world, research topics are all from (1) to (7), but in Vietnam due to lower development we only focus on the simple topics including (1) to (4). Because of a large number (165 thousands) of publications in this topic with the keyword antagonist in Medline, so I just concentrated overview of topic (5) in the world that we will do and topics (1) to (4) in Vietnam.

Bacillus is a Gram-positive, rod-shaped bacterium commonly found in soil. It has a high thermal tolerance, grows rapidly in liquid medium, and produces many spores. The bacterium can also produce antibiotics that inhibit or kill other microorganisms and have a positive or negative impact on bacterial and fungal diseases. Recently, a number of $B$. subtilis strains were used to control plant diseases $[10,17]$. In addition, The Rhizoctonia solani and Fusarium oxysporum are two widespreads phytopathogenic fungi. Both of them can survive for a long time in soil and infect many agricultural and industrial plants including leguminous crops, solanaceous crops, cucurbits, cotton plants, etc. These pathogenic fungi caused black root rot symptoms, ulcer roots, stem rot, rotting leaves. Indeed, they can infect seedlings and may remain on the plants until the first harvest $[2,3]$.

Investigation of the thermal stability of antifungal compounds from the Bacillus will helping to the bio-products restricted oxidation process under the effect of the conditions such as light, high temperature, $\mathrm{pH}$... Here, we purified and assessed of antifungal protein from Bacillus subtilis isolated in Vietnam. The purified antifungal protein was also identified and investigated for its thermal stability to help bio-products.

\section{Materials and methods}

\subsection{Microorganisms}

The F. oxysporum and $R$. solani strains were provided by the Plant Diseases Division at the Institute of Plant Protection, Tu Liem, Ha Noi.

Bacillus subtilis was supplied by the Department of Enzyme Biotechnology at the Institute of Biotechnology, Vietnam Academy of Science and Technology. Bacillus subtilis was grown in NYD medium $(\mathrm{pH} 7.5)$, which comprised glucose $(10 \mathrm{~g} / \mathrm{L})$, beef extract $(8 \mathrm{~g} / \mathrm{L})$, and yeast extract $(5 \mathrm{~g} / \mathrm{L})$.

\subsection{Chemicals}

Sodium chloride and D-glucose were purchased from Merck (Darmstadt, Germany). Minisart membranes and agar were purchased from Biotech (Vietnam). DEAE cellulose, Biogel P100, Trisbase and Bovine serum albumin (BSA) were supplied by Sigma-Aldrich (St. Louis, $\mathrm{MO}, \mathrm{USA}$ ). $\mathrm{NaHPO}_{4}, \mathrm{Na}_{2} \mathrm{HPO}_{4}$, meat extract, and yeast extract were purchased from BioBasic Inc. (Ontario, Canada).

\subsection{Methods}

\subsubsection{Antifungal protein purification}

The bacterial culture was centrifuged at $12500 \mathrm{rpm}$ for 10 min. Ammonium sulfate (30-70\% saturation) was then slowly added to $200 \mathrm{ml}$ of crude protein solution with constant stirring. The mixture was left overnight and then centrifuged at $12500 \mathrm{rpm}$ for $10 \mathrm{~min}$. The supernatant was then carefully decanted, and the precipitate was redissolved in $0.02 \mathrm{M}$ phosphate buffer ( $\mathrm{pH}$ 6.8) and dialyzed to remove the salt. The dialyzed fraction $(6 \mathrm{ml})$ was then applied to a DEAE -cellulose column $(2.6 \times 6 \mathrm{~cm})$ pre-equilibrated with $0.02 \mathrm{M}$ phosphate buffer $(\mathrm{pH} 6.8)$ at a flow rate of $25 \mathrm{ml} / \mathrm{hr}$ until the OD $280 \mathrm{~nm}$ was $<0.01$. The column was then eluted with $0.02 \mathrm{M}$ phosphate buffer ( $\mathrm{pH} \mathrm{6.8)} \mathrm{containing} 1 \mathrm{M} \mathrm{NaCl}$. The eluted fractions of $1.5 \mathrm{ml}$ were collected (27 fractions). The antifungal activity of each purified fraction was tested against $F$. oxysporum and $R$. solani. Fractions with strong antifungal activity were continuously purified on a Biogel P100 column. The column was then eluted with $0.02 \mathrm{M}$ phosphate buffer ( $\mathrm{pH} \mathrm{6.8)} \mathrm{at} \mathrm{a} \mathrm{flow} \mathrm{rate} \mathrm{of} 25 \mathrm{ml} / \mathrm{hr}$ and $1.5 \mathrm{ml}$ fractions were collected. The antifungal activity of the purified fractions was once again tested against the two above pathogenic fungi. All purification steps were carried out at $4^{\circ} \mathrm{C}$ unless specified otherwise.

\subsubsection{Antifungal activity of the purified protein determination}

To test antifungal for purification and characterization of an antifungal protein, ampicillin $(0.1 \%)$ was added to petri plates $(90 \times 15 \mathrm{~mm})$ containing $10 \mathrm{ml}$ of PDA (a mycelial plug from 4-day-old cultures of $F$. oxysporum or $R$. solani was placed in the center of the PDA plates), and filter papers $(0.5 \mathrm{~cm}$ in diameter) soaked with $15 \mu \mathrm{l}$ of purified protein were placed on the surface. The agar plates were then incubated at $30^{\circ} \mathrm{C}$ for $3-5$ days (Incubator, Sanyo, Japan). As a control, filter papers were soaked in $0.02 \mathrm{M}$ phosphate buffer ( $\mathrm{pH} 6.8)$.

\subsubsection{SDS-PAGE and protein concentration}

SDS-PAGE was carried out as described by Laemmli (1970) [4] with Bio-Rad equipment. SDS-PAGE was usually performed on gels containing $12.5 \% \quad(\mathrm{w} / \mathrm{v})$ acrylamide according to the manufacture's recommendation. The gels were stained with Coomassie Brilliant Blue R-250 for protein. Protein was estimated by the method of Bradford with the bovine serum albumin as standard [5].

\subsubsection{Thermal stability}

The thermal stability of the chitin binding protein was determined by incubating purified protein $(20 \mu \mathrm{l})$ at $80^{\circ} \mathrm{C}$ for $5-60 \mathrm{~min}$ or at $100^{\circ} \mathrm{C}$ for $60 \mathrm{~min}$. Antifungal activity was then determined as described above.

\subsubsection{Protein identification}

The purified antifungal protein was identified by MALDI -TOF MS. The sample was trypsin digested and peptides 
extracted according to standard techniques. Peptides were analysed by MALDI -TOF/TOF mass spectrometer using a 5800 Proteomics Analyzer [AB Sciex]. Spectra were analysed to identify protein of interest using Mascot sequence matching software [Matrix Science] with MSPnr100 Database. Peptide fragments showing ion scores $>59$ were identified uniquely or high -similarly $(\mathrm{p}$ $<0.01)$

\subsubsection{Statistical analysis}

All measurements were carried out in triplicate. The means were presented for averages of experiments.

\section{Results}

\subsection{Purification and identification of antifungal protein}

After $120 \mathrm{hr}$ of cultivation, the crude supernatant of $B$. subtilis was purified by addition of $30-70 \%$ ammonium sulfate, followed by passage over a DEAE - cellulose column. Three range of fractions containing high protein concentration were observed (corresponding to peaks 1, 2, and 3 ). These fractions were tested for antifungal activity against $F$. oxysporum and all were positive (data not shown). Fractions 5-11 from peak 1 were then mixed and passed over a Biogel P100 column. The purity and relative molecular mass of the proteins were assessed by $12.5 \%$ polyacrylamide gel electrophoresis with Fermentas protein standards, followed by silver staining. A protein

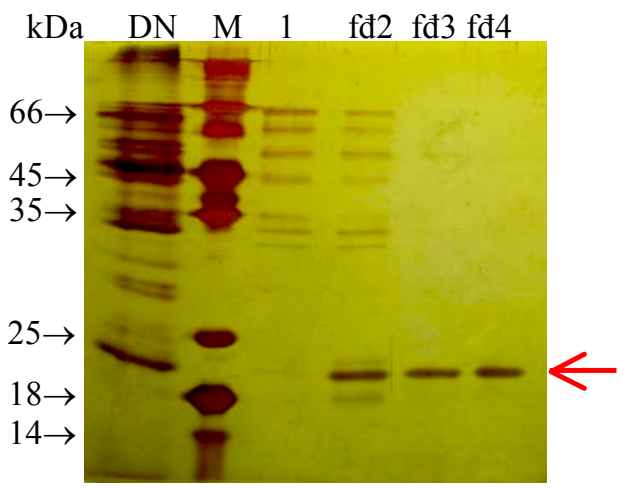

A of $\sim 22 \mathrm{kDa}$ was observed (Fig. 1A) with the yield of the purification process was $11.9 \%$ (data not show).

In oder to find out the element responsible for the antifungal activity of $B$. subtilis, the supernatant was precipitated by addition of $30-70 \%$ ammonium sulfate, and then was continuously purified using ion exchange chromatography on DEAE-cellulose and Biogel P100 chromatography. These methods also used for the purification some protein from bacteria and fungi by other studies [6, 7]. Indeed, ion exchange chromatography on DEAEcellulose, followed by Biogel P100 chromatography, has been used to extract other proteins with antifungal activity $[8,9]$. In our study, the purified protein with molecular weight of $22 \mathrm{kDa}$ has activity against both of $F$. oxysporum and $R$. solani (Fig. 1A and 1B). The molecular weight of this antifungal protein was different from that of other antifungal proteins purified from B. subtilis. Liu et al. (2007) extracted bacisubin from B. subtilis B916, which has a molecular weight of $41.9 \mathrm{kDa}$ and exhibits antifungal activity against $F$. oxysporum and $R$. solani [9]. Li et al. (2009) extracted protein B29I from B. subtilis strain B29, which has a molecular weight of $42.9 \mathrm{kDa}$ and shows antifungal activity [10]. Tan et al. (2013) purified antifungal protein with molecular weight of $38 \mathrm{kDa}$ from B. subtilis B25[11]. The difference in antifungal peptides produced by different strains of $B$. subtilis may be due to the fact that "biosynthesis of antibiotics from microorganisms is often regulated by nutritional and environmental factors" [12].

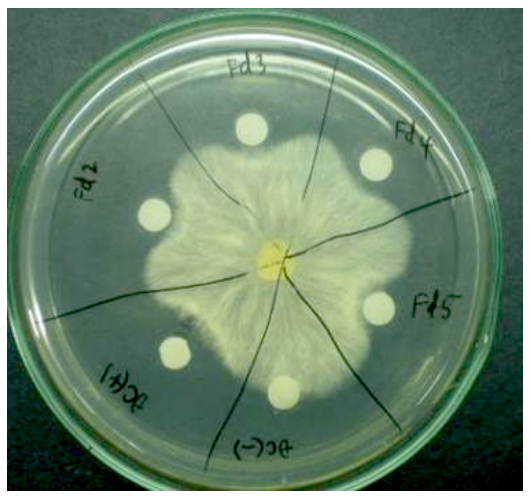

B

Figure 1. (A) Protein profile on SDS -PAGE of the crude supernatant (Lane 1), fractions from peak 1 after passage through the Biogel P100 column (Lane 2), M: molecular mass of standard proteins (Fermentas, Thermo Fisher Scientific Inc.,Waltham, USA); (B) Anti $-F$. oxysporum activity of the purified protein (ĐC(-): 20 mM sodium phosphate buffer, $\mathrm{pH} 6.8$; $\mathrm{ÐC}(+)$ : the crude supernatant; Fd 2-Fd 4: the fraction purified protein from fraction 2- 4 .

\subsection{Protein identification}

The purified protein was then identified by MALDI-TOF mass spectrometry. Peptide fragments showing ion scores above 59 identified uniquely or high - similarly with $\mathrm{p}<$ 0.01 . These peptides were $100 \%$ identical to corresponding fragments of the chitin binding protein (Table 1).

Chitin binding protein from Bacillus (Accession number: WP_003154023) has 206 acid amine containing chitin -bind -3 region such as "Chitin binding domain; pfam03067" from acid amine position 28 to 202 with a relative molecular mass of $22230 \mathrm{Da}$. Using MALDI-TOF mass spectrometry to identified the purified protein, we found that it is a chitin-binding protein. This result was matched with other reports that chitin-binding proteins have play an important role in the protection of plants against pathogen infection [13, 14]. The mechanisms against fungal attack of chitin binding proteins was supposed to take part in degrading chitin and/or adhering to the chitinous surfaces of host cells $[15,16]$. 
Table 1. Peptides exceeding the identity threshold

\begin{tabular}{lllll} 
Query & Observed & Peptide mass & Score & Peptide sequence \\
\hline 151 & 450.2341 & 898.4508 & 62 & ADTNLTHK \\
223 & 521.2684 & 1040.5040 & 67 & GFPAAGPPDGR \\
312 & 587.8201 & 1173.6142 & 64 & QTLGWTAAAQK \\
491 & 795.4013 & 1588.7733 & 97 & YGSVIDNPQSVEGPK \\
492 & 795.4013 & 1588.7733 & 99 & YGSVIDNPQSVEGPK \\
522 & 825.4164 & 1648.8057 & 146 & IASANGGSGQIDFGLDK \\
527 & 830.9003 & 1659.7740 & 106 & DEFELIGTVNHDGSK \\
669 & 881.1017 & 2640.2820 & 141 & IASANGGSGQIDFGLDKQTADYWVK
\end{tabular}

\subsection{Effect of temperature and thermostability}

The effect of temperature on the chitin binding protein min. The results show that the chitin binding protein retained activity when heated to $80^{\circ} \mathrm{C}$ and even to $100^{\circ} \mathrm{C}$ for $60 \mathrm{~min}$ (Fig. 2A and 2B).

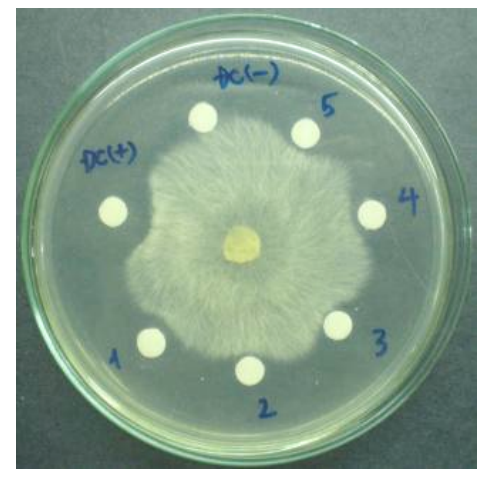

A

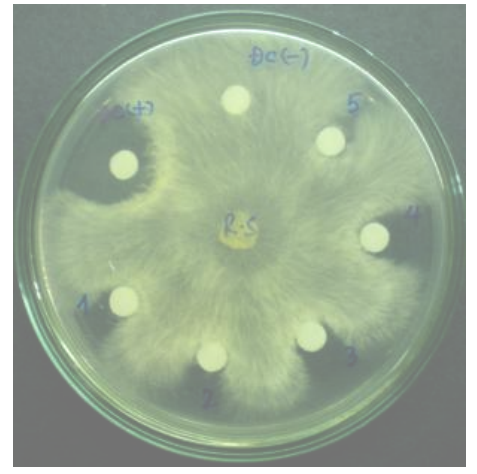

B

Figure 2. Effects of temperature on the antifungal activity of the chitin binding protein against $F$. oxysporum (A) and $\boldsymbol{R}$. solani (B), (ĐC(-): control $(20 \mu \mathrm{l}$ of $20 \mathrm{mM}$ sodium phosphate buffer, $\mathrm{pH} 6.8)$; ĐC(+): the crude supernatant; $1-4$ : Samples treated at $80^{\circ} \mathrm{C}$ for 5-60 min; 5: sample treated at $100^{\circ} \mathrm{C}$ for $60 \mathrm{~min}$ )

The chitin binding protein is also quite thermostable as it retained activity when heated to $80^{\circ} \mathrm{C}$ and even to $100^{\circ} \mathrm{C}$ for $60 \mathrm{~min}$. This result was coincident with some previous studies. Zang et al. (2008) purified a novel proteinBTL- from Bacillus strain B-TL2 from tobacco stems was also thermostable, retaining almost $100 \%$ activity when heated to $100^{\circ} \mathrm{C}$ for $15 \mathrm{~min}$ [17]. Chitarra et al. (2003) reported that an antifungal compound produced by $B$. subtilis YM 10-20 was heat stable. The protein inhibited the growth of $P$. roqueforti after heating to $70^{\circ} \mathrm{C}$ or $100^{\circ} \mathrm{C}$ for $1 \mathrm{hr}$ [18]. The above mentioned result of MALDI -TOF indicated that the purified protein TOF was chitin binding protein may give us logical explanation for this thermal stability.

\section{Conclusions}

We successfully purified chitin binding protein from Bacillus subtilis. The chitin binding protein is also very thermostable as it retained activity when heated to $80^{\circ} \mathrm{C}$ and even to $100^{\circ} \mathrm{C}$ for $60 \mathrm{~min}$.

Acknowledgement: This study was supported by the National Foundation for Science and Technology Development Vietnam (Nafosted), project 106.052012.35: "Screening, extraction, purification and structure analysis of some novel antagonistic compounds (or derivatives) against Fusarium and Rhizoctonia from Bacillus, Burkholderia, Pseudomonas and Serratia isolates in Vietnam"), 2013-2015. The authors are thankful Prof. Quyen Dinh Thi for guidance.

\section{References}

[1] Gerhardson B: Biological substitutes for pesticides. Trends Biotechnol 2002, 20:338-343.

[2] Garbeva P, van Veen JA, van Elsas JD: Assessment of thediversity, and antagonism towards Rhizoctonia solani AG3, of Pseudomonas species in soil from different agricultural regimes. FEMS Microbiology Ecology 2004, 47:51-64.

[3] Alabouvette C: Fusarium wilt-suppressive soils from the Cha-teaurenard region: review of a 10 -year study. Agronomie 1986, 6.

[4] Laemmli UK: Cleavage of structure proteins during the assembly of the head of bacteriophage T4. $\mathrm{Na}$ ture 1970, 227:680- 685 .

[5] Bradford MN: A rapid and sensitive method for the quantitation of microgram quantities of protein utilizing the principle of protein-dye binding. Anal Bio- 
chem 1976, 72:248- 254.

[6] Wang $\mathrm{H}, \mathrm{Ng} \mathrm{TB}$ : Isolation of cicadin, a novel and potent antifungal peptide from juvenile cicadas. Peptides 2002, 23(1):7-11.

[7] Ngai PHK, Zhao Z, Ng TB: Agrocybin, an antifungal peptide from the edible mushroom Agrocybe cylindracea. Peptides 2005, 26(2):191-196.

[8] Lam YW, Wang HX, Ng TB: A robust cysteinedeficient chitinase-like antifungal protein from inner shoots of the edible chive Allium tuberosum. Biochem Biophys Res Commun 2000, 279(1):74-80.

[9] Liu Y, Chen Z, Ng TB, Zhang J, Zhou M, Song F, Lu F, Liu Y: Bacisubin, an antifungal protein with ribonuclease and hemagglutinating activities from Bacillus subtilis strain B-916. Peptides 2007, 28(3):553-559.

[10] Li J, Yang Q, Zhao L, Zhang S, Wang Y, Zhao X: Purification and charracterization of a novel antifungal protein from Bacillus subtilis strain B29. Journal of Zhejiang University Science B 2009, 10(4):264272.

[11] Tan Z, Lin B, Zhang R: A novel antifungal protein of Bacillus subtilis B25. Springer plus 2013, 2:543549.

[12] Islam MR, Jeong YT, Lee YS, Song CH: Isolation and identification of antifungal compounds from $\mathrm{Ba}$ - cillus subtilis C9 inhibiting the growth of plant pathogenic fungi. Mycobiology 2012, 40(1):59-66.

[13] Nielsen KK, Nielsen JE, Madrid SM, Mikkelsen JD: Characterization of a new antifungal chitin-binding peptide from sugar beet leaves. Plant Physiol 1997, 113:83-91.

[14] Bormann C, Baier D, Horr I, Raps C, Berger J, Jung G: Characterization of a novel, antifungal, chitinbinding protein from Streptomyces tendae Tu901 that interferes with growth polarity. $J$ Bacteriol 1999, 181:7421-7429.

[15] Vaaje-Kolstad G, Horn SJ, van Aalten DM, Synstad B, Eijsink VG: The non-catalytic chitin-binding protein CBP21 from Serratia marcescens is essential for chitin degradation. $J$ Biol Chem 2005, 280(31):28492-28497.

[16] Bhattacharya D, Nagpure A, Gupta RK: Bacterial chitinases: properties and potential. Crit Rev Biotechnol 2007, 27(1):21-28.

[17] Zhang B, Xie C, Yang X: A novel small antifungal peptide from Bacillus strain B-TL2 isolated from tobacco stems. Peptides 2008, 29:350- 355.

[18] Chitarra GS, Breeuwer P, Nout MJR, van Aelst AC, Rombouts FM, Abee T: An antifungal compound produced by Bacillus subtilis YM 10-20 inhibits germination of Penicillium roqueforti conidiospores. J Appl Microbiol 2003 94:159-166. 